\title{
Metal-Dithiolenes of Disubstituted Imidazolidine-2,4,5-trithione Monoanion. An Electrochemical and EPR Study
}

\author{
E. Grigiotti, ${ }^{a}$ F. Laschi, ${ }^{a}$ P. Zanello,,${ }^{a}$ M. Arca, ${ }^{\text {, }}$ \\ C. Denotti, ${ }^{\mathrm{b}}$ F.A. Devillanova ${ }^{\mathrm{b}}$ \\ ${ }^{a}$ Dipartimento di Chimica, Università degli Studi di Siena, Via A. Moro, 53100 Siena, Italy. \\ ${ }^{b}$ Dipartimento di Chimica Inorganica ed Analitica, Università degli Studi di Cagliari, S.S. 554 \\ bivio per Sestu, 09042 Monserrato, Cagliari, Italy
}

Received 30 September 2003

\begin{abstract}
The electrochemical properties of a series of $\left[\mathrm{M}\left(\mathrm{R}, \mathrm{R}{ }^{\prime} \text { timdt }\right)_{2}\right]$ dithiolenes $(\mathrm{M}=\mathrm{Ni}, \mathrm{Pd}$, Pt; R,R'timdt = monoanion of disubstituted imidazolidine-2,4,5-trithione) have been studied by cyclic voltammetry, controlled potential coulometry, and EPR spectroscopy. All the compounds undergo two separate one-electron reductions and one two-electron oxidation, which proceed through a single step in the case of nickel complexes, and through two separate steps in the case of palladium and platinum complexes. Inductive effects played by the $\mathrm{R}$ and $\mathrm{R}$ ' substituents influence the formal electrode potentials of the electron transfer processes. EPR spectroscopy has proved that the unpaired electron in monoanions $\left[\mathrm{M}\left(\mathrm{R}, \mathrm{R}{ }^{\prime} \text { timdt }\right)_{2}\right]^{-}$is located on a SOMO, which, even if mainly ligand centred, is significantly contributed by the metal.
\end{abstract}

\section{Introduction}

During the last years, a great deal of attention has been paid to the properties of non-linear optical (NLO) materials, because of their multiple applications to different technological fields, ranging from data storage to optical switches, and

\footnotetext{
* Corresponding author. E-mail address: zanello@unisi.it
} 
from telecommunications to laser technologies [1]. In particular, coordination compounds with extended $\pi$-delocalisation, such as metal-dithiolenes, represent good candidates. In fact, these can exhibit high electrical conduction [2], intense absorption in the visible-NIR region [3], high thermal and photochemical stability [4], and easy access to several reversible redox states [5].

In this framework, a series of widely substituted metal-dithiolenes belonging to the general class $\left[\mathrm{M}(\mathrm{R}, \mathrm{R} \text { 'timdt })_{2}\right](\mathrm{M}=\mathrm{Ni}, \mathrm{Pd}, \mathrm{Pt}$; R,R'timdt = monoanion of disubstituted imidazolidine-2,4,5-trithione; Scheme 1), has been synthesised and different kinds of studies have been carried out for their exhaustive characterization [4-12].

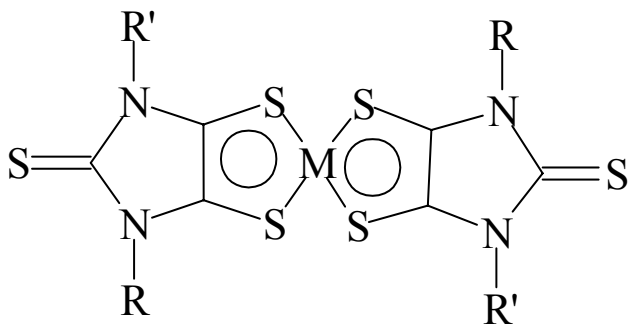

$M=$ Ni, Pd, Pt

Scheme 1

The peculiar position of very intense absorption in the NIR region (991-1053 nm in $\left.\mathrm{CHCl}_{3}\right)$ as well as the other physical-chemical properties of [M(R,R'timdt $\left.)_{2}\right]$ dithiolenes strongly depend upon the nature of $\mathrm{M}, \mathrm{R}$ and $\mathrm{R}$ '[4,11]. The tuning of the position of the NIR absorption band has been employed in the attempt to obtain compounds exactly matching the laser emission wavelength and therefore suitable as Q-switching or mode locking dyes [3,10]. In fact, the NIR-absorption wavelengths of $\left[\mathrm{M}(\mathrm{R}, \mathrm{R} \text { 'timdt })_{2}\right]$ dithiolenes showed to be able to match the emission wavelengths of the Nd:YLF and Nd:YAG lasers (1053 and $1064 \mathrm{~nm}$, respectively) [11]. In addition, photoconducting properties have been reported for the neutral complexes $[13,14]$. From the electrochemical point of view, the redox non-innocence of the R,R'timdt ligand gives rise to the possibility of different charged ions $[5,15,16]$. The proper choice of the substituents as well as of the 
metal could make possible to control the potential values for the planned access to the different ionic forms. In this paper, we report a deep CV and EPR study performed on a large number of variously substituted [M(R,R'timdt $\left.)_{2}\right]$ dithiolenes, summarised in Table 1.

\section{Experimental}

The neutral dithiolenes $\left[\mathrm{M}\left(\mathrm{R}, \mathrm{R}^{\prime} \text { timdt }\right)_{2}\right]$, listed in Table 1 , have been synthesised and characterised according to the procedure previously reported $[9,10]$.

\section{Electrochemistry}

Anhydrous 99.9\% (HPLC grade) $\mathrm{CH}_{2} \mathrm{Cl}_{2}$ was obtained from Aldrich. Electrochemical grade $\left[\mathrm{NBu}_{4}\right]\left[\mathrm{PF}_{6}\right]$ supporting electrolyte was purchased from Fluka. Cyclic voltammetry measurements were performed in a three-electrode cell containing a platinum working electrode surrounded by a platinum-spiral counter electrode and an aqueous saturated calomel reference electrode (SCE) mounted with a Luggin capillary. A BAS $100 \mathrm{~W}$ electrochemical analyser was used as polarising unit. Controlled potential coulometry was performed in a $\mathrm{H}$ shaped cell with anodic and cathodic compartments separated by a sintered-glass disk. The working macroelectrode was a platinum gauze; a mercury pool was used as the counter electrode.

All the potential values are referred to the saturated calomel electrode (SCE). Under the present experimental conditions, the one-electron oxidation of ferrocene occurs at $\mathrm{E}^{\circ}=+0.39 \mathrm{~V}$.

Due to the low solubility of several neutral complexes, cyclic voltammetries were performed on the corresponding electrogenerated monoanions, which resulted soluble.

\section{EPR studies}

X-band electron spin resonance (ESR) spectra were recorded with a ER 200 DSRC Bruker spectrometer operating a $v=9.44 \mathrm{GHz}$ using a HS Brucker rectangular cavity. The control of the operational frequency was obtained with a Hewlett-Packard X 5-32 B wavemeter and the magnetic field was calibrated with 
a DPPH (diphenylpicrylhydrazyl) free radical as a suitable field marker. The control of the temperature was obtained with a Bruker ER 4111 VT device $( \pm 1 \mathrm{~K})$. The $\mathrm{g}$ values are referred to DPPH $(\mathrm{g}=2.0036)$ used as the external standard reference.

\section{Results and Discussion}

\section{Electrochemistry}

Fig. 1 compares the cyclic voltammetric behaviour of complexes $\left[\mathrm{M}\left(\mathrm{Et}_{2} \mathrm{timdt}_{2}\right]\right.$ $(\mathrm{M}=\mathrm{Ni}, \mathrm{Pd}, \mathrm{Pt})$.

(a)
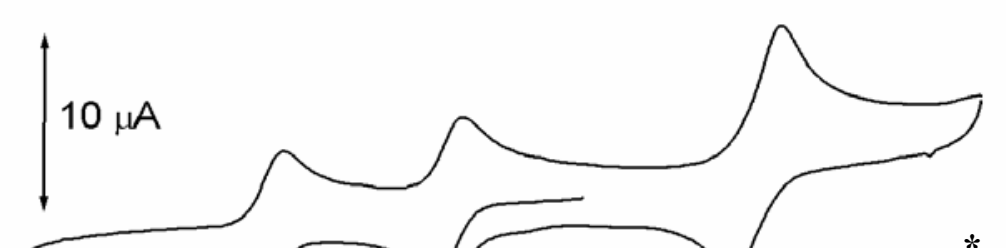

(b)
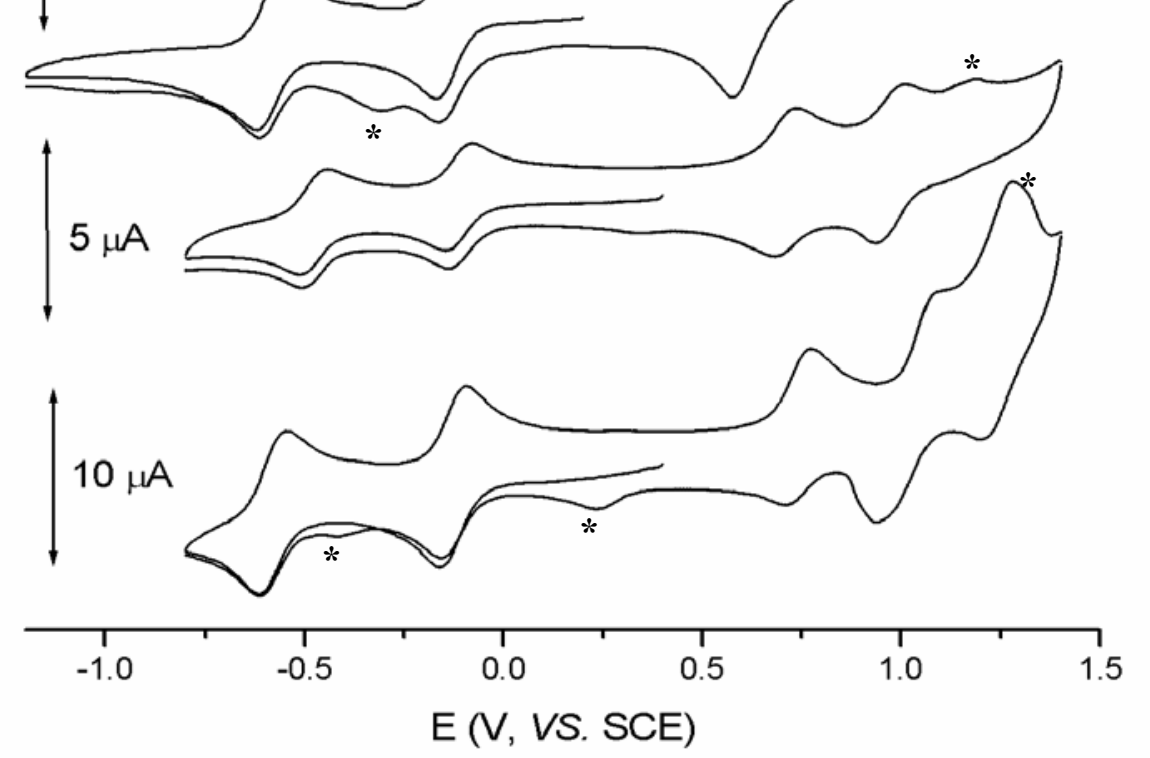

Figure 1. Cyclic voltammetric responses recorded at a platinum electrode in $\mathrm{CH}_{2} \mathrm{Cl}_{2}$ solutions containing $\left[\mathrm{NBu}_{4}\right]\left[\mathrm{PF}_{6}\right]\left(0.2 \mathrm{~mol} \mathrm{dm}^{-3}\right)$ and: (a) $\left[\mathrm{Ni}\left(\mathrm{Et}_{2} \text {-timdt }\right)_{2}\right]\left(5 \times 10^{-4} \mathrm{~mol}^{-3}\right.$

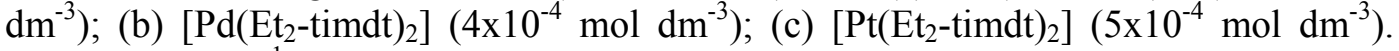
Scan rate $0.2 \mathrm{Vs}^{-1}$.

In agreement with previous findings [9], the nickel complex undergoes two reductions and one oxidation (Fig. 1a). The reduction processes display chemical reversibility in the cyclic voltammetric time scale, whereas the oxidation process is partially chemically reversible $\left(i_{\mathrm{pc}} / i_{\mathrm{pa}}=0.7\right.$ at $\left.0.2 \mathrm{~V} \cdot \mathrm{s}^{-1}\right)$, as on the other hand proved by the appearance of a spurious (starred) peak in the backscan. Step-by- 
step controlled potential coulometry in correspondence to the cathodic processes proved their gradual consumption of one electron per molecule. Cyclic voltammetry performed on the exhaustively reduced solutions afforded cyclic voltammetric profiles quite complementary to the original ones, thus confirming the complete stability of the $\left[\mathrm{Ni}\left(\mathrm{Et}_{2} \mathrm{timdt}\right)_{2}\right]^{-}$and $\left[\mathrm{Ni}\left(\mathrm{Et}_{2} \mathrm{timdt}\right)_{2}\right]^{2-}$ anions. Upon electrogenerating the monoanion $\left[\mathrm{Ni}\left(\mathrm{Et}_{2} \mathrm{timdt}_{2}\right]^{-}\right.$, the original neutral green solution turns dark red, while the further reduction to the dianion $\left[\mathrm{Ni}\left(\mathrm{Et}_{2} \mathrm{timdt}\right)_{2}\right]^{2-}$ affords a violet solution. In contrast, it was not possible to evaluate the number of electrons involved in the anodic process because of absorption phenomena at the electrode surface. However, since that the peak height of this latter is roughly twice than that of each reduction step, we assign it as a two-electron process.

Two one-electron reductions also occur for the palladium complex, according to the sequence $\left[\mathrm{Pd}\left(\mathrm{Et}_{2} \text { timdt }\right)_{2}\right]^{0} /\left[\mathrm{Pd}\left(\mathrm{Et}_{2} \text { timdt }\right)_{2}\right]^{-} /\left[\mathrm{Pd}\left(\mathrm{Et}_{2} \text { timdt }\right)_{2}\right]^{2-} \quad($ Fig. 1b). Starting from the violet colour of the neutral Pd-complex no appreciable colour changes accompany the bulk electrolysis experiments performed to generate the monoanion. The first reduction features chemical reversibility either in the time scale of cyclic voltammetry or bulk electrolysis, whereas the second reduction is coupled to slow chemical degradation. Unexpectedly, differently to what observed in the case of the nickel analogue [7,9], the anodic path shows two oneelectron oxidations possessing features of chemical reversibility according to the sequence $\left[\mathrm{Pd}\left(\mathrm{Et}_{2} \mathrm{timdt}\right)_{2}\right]^{0} /\left[\mathrm{Pd}\left(\mathrm{Et}_{2} \mathrm{timdt}\right)_{2}\right]^{+} /\left[\mathrm{Pd}\left(\mathrm{Et}_{2} \mathrm{timdt}\right)_{2}\right]^{2+}$, even if the appearance of a further minor (starred) peak testifies to the partial chemical stability of the $\left[\mathrm{Pd}\left(\mathrm{Et}_{2} \mathrm{timdt}\right)_{2}\right]^{2+}$ dication.

The redox behaviour of the platinum complex (Fig. 1c) is quite similar to that of the palladium dithiolene, but for the higher decomposition rate of the dication (see the spurious starred peaks). Exhaustive one-electron reduction makes the colour of the original solution change from grey-violet to green, whereas the monocationic species assumes a pink-brown colour.

It hence results that, independently from the nature of $M, R$ and $R$ ', $\left[M\left(E t_{2}-\right.\right.$ timdt $)_{2}$ ] complexes are able to undergo two separate one-electron reductions and 
two one-electron oxidations, which occur at separate potential values in the case of palladium and platinum complexes, and at coincident potential values for the nickel complexes.

In general, all the monoanions and monocations are indefinitely stable, whereas the dianions and the dications undergo relatively slow decomposition. In this connection, we note that chemical oxidation of $\left[\mathrm{Pd}\left(\mathrm{Et}_{2} \mathrm{timdt}\right)_{2}\right]$ by bromine follows the path depicted in Scheme 2 [17,18], while the oxidation of the $\left[\mathrm{Ni}\left(\operatorname{Pr}_{2}^{\mathrm{i}}{ }_{2} \mathrm{timdt}\right)_{2}\right]$ dithiolene led to the complete elimination of the metal yielding the corresponding organic tetrathiocino product [19].

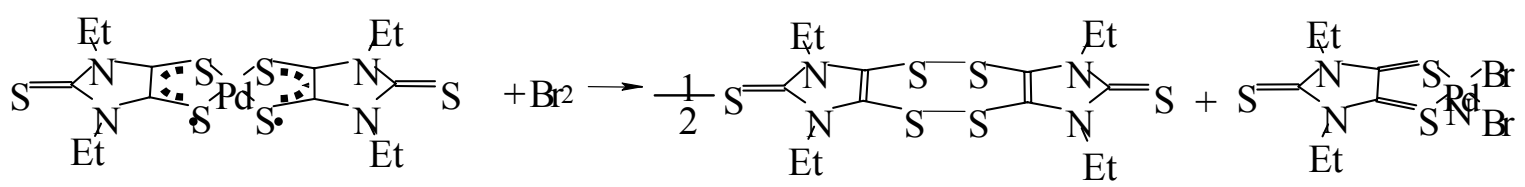

\section{Scheme 2}

The formal electrode potentials for all the redox processes are compiled in Table 1. 
Table 1. Formal electrode potentials (V, vs. SCE) for the redox processes exhibited by $\left[\mathrm{M}(\mathrm{R}, \mathrm{R} \text { 'timdt })_{2}\right]$ complexes in $\mathrm{CH}_{2} \mathrm{Cl}_{2}$ solution. $\left[\mathrm{NBu}_{4}\right]\left[\mathrm{PF}_{6}\right](0.2 \mathrm{M})$ supporting electrolyte.

\begin{tabular}{|c|c|c|c|c|c|c|}
\hline & \multicolumn{2}{|c|}{ Complex } & \multicolumn{2}{|c|}{ Oxidations } & \multicolumn{2}{|c|}{ Reductions } \\
\hline $\mathbf{M}$ & $\mathbf{R}$ & $\mathrm{R}^{\prime}$ & $\mathbf{E}^{\circ}(2+/+)$ & $E^{09}(+/ 0)$ & $E^{09}(0 /-)$ & $\mathbf{E}^{\circ}(-/ 2-)$ \\
\hline \multirow{10}{*}{$\mathrm{Ni}$} & $\mathrm{Me}$ & Me & & $+0.64^{\mathrm{a}}$ & -0.13 & -0.58 \\
\hline & $\mathrm{Me}$ & $p-\mathrm{Cl}-\mathrm{C}_{6} \mathrm{H}_{4}$ & & $+0.73^{\mathrm{a}}$ & 0.00 & -0.46 \\
\hline & $\mathrm{Me}$ & $p-\mathrm{MeO}_{-} \mathrm{C}_{6} \mathrm{H}_{4}$ & & $+0.65^{\mathrm{a}}$ & -0.10 & -0.58 \\
\hline & $\mathrm{Et}$ & Et & & $+0.65^{\mathrm{a}}$ & -0.14 & -0.59 \\
\hline & Et & Pentyl & & $+0.74^{\mathrm{a}}$ & -0.17 & -0.63 \\
\hline & Et & $\mathrm{Ph}$ & & $+0.73^{\mathrm{a}}$ & -0.10 & -0.56 \\
\hline & Et & Naphthyl & & $+0.74^{\mathrm{a}}$ & -0.09 & -0.58 \\
\hline & ${ }^{\mathrm{i}} \operatorname{Pr}$ & $m-C F_{3}-C_{6} H_{4}$ & & $+0.79^{\mathrm{a}, \mathrm{b}, \mathrm{c}}$ & $-0.06^{\mathrm{c}}$ & $-0.53^{c}$ \\
\hline & $\mathrm{Ph}$ & $\mathrm{Ph}$ & $+1.20^{\mathrm{b}}$ & $+0.73^{\mathrm{a}}$ & -0.04 & -0.52 \\
\hline & $p-\mathrm{F}-\mathrm{C}_{6} \mathrm{H}_{4}$ & Naphthyl & & $+0.82^{\mathrm{a}, \mathrm{b}}$ & -0.05 & -0.55 \\
\hline \multirow{14}{*}{$\mathrm{Pd}$} & $\mathrm{Me}$ & iPr & +0.96 & +0.70 & -0.09 & -0.47 \\
\hline & $\mathrm{Me}$ & $p-C l-C_{6} H_{4}$ & +0.94 & +0.80 & +0.04 & -0.35 \\
\hline & $\mathrm{Me}$ & $m-\mathrm{CF}_{3}-\mathrm{C}_{6} \mathrm{H}_{4} \mathrm{CH}_{2}$ & +1.02 & +0.78 & -0.02 & -0.40 \\
\hline & $\mathrm{Me}$ & $p-\mathrm{NO}_{2}-\mathrm{C}_{6} \mathrm{H}_{4}$ & $+1.00^{\mathrm{d}}$ & +0.81 & +0.06 & -0.31 \\
\hline & $\mathrm{Et}$ & Et & +0.97 & +0.71 & -0.12 & -0.49 \\
\hline & Et & Pentyl & +0.98 & +0.71 & -0.10 & -0.48 \\
\hline & Et & $\mathrm{Ph}$ & +1.00 & +0.74 & -0.06 & -0.44 \\
\hline & Et & Naphthyl & +0.99 & +0.74 & -0.07 & -0.47 \\
\hline & ${ }^{\mathrm{i}} \operatorname{Pr}$ & $m-C F_{3}-C_{6} H_{4}$ & +1.04 & +0.80 & -0.01 & -0.40 \\
\hline & $\mathrm{Ph}$ & $\mathrm{Ph}$ & +1.00 & +0.74 & +0.01 & -0.38 \\
\hline & $p-\mathrm{F}-\mathrm{C}_{6} \mathrm{H}_{4}$ & $p-\mathrm{F}-c_{6} \mathrm{H}_{4}$ & +1.00 & +0.77 & +0.04 & -0.38 \\
\hline & $p-\mathrm{F}-\mathrm{C}_{6} \mathrm{H}_{4}$ & $p-\mathrm{NO}_{2}-\mathrm{C}_{6} \mathrm{H}_{4}$ & +1.04 & +0.82 & +0.09 & -0.31 \\
\hline & $p-\mathrm{F}-\mathrm{C}_{6} \mathrm{H}_{4}$ & $m, m, p-\left(\mathrm{CH}_{3} \mathrm{O}\right)_{3}-\mathrm{C}_{6} \mathrm{H}_{4}$ & $+1.04^{\mathrm{b}}$ & +0.73 & +0.05 & -0.37 \\
\hline & $p-\mathrm{F}-\mathrm{C}_{6} \mathrm{H}_{4}$ & Naphthyl & +1.03 & +0.80 & +0.01 & -0.41 \\
\hline \multirow{16}{*}{$\mathrm{Pt}$} & $\mathrm{Me}$ & Me & $+0.91^{\mathrm{e}}$ & +0.69 & -0.06 & -0.43 \\
\hline & $\mathrm{Me}$ & ${ }^{i} \mathrm{Pr}$ & $+1.06^{\mathrm{b}}$ & +0.76 & -0.11 & -0.58 \\
\hline & Me & Pentyl & $+1.13^{\mathrm{b}}$ & +0.77 & -0.06 & -0.55 \\
\hline & $\mathrm{Me}$ & $p-C l-C_{6} \mathrm{H}_{4}$ & $+1.09^{\mathrm{b}}$ & +0.81 & 0.00 & -0.48 \\
\hline & $\mathrm{Me}$ & $m-C_{3}-C_{6} H_{4} C H_{2}$ & +1.11 & +0.82 & -0.02 & -0.51 \\
\hline & $\mathrm{Me}$ & $p-\mathrm{NO}_{2}-\mathrm{C}_{6} \mathrm{H}_{4}$ & $+1.10^{\mathrm{b}}$ & +0.81 & -0.09 & -0.48 \\
\hline & $\mathrm{Et}$ & Et & +1.03 & +0.74 & -0.13 & -0.59 \\
\hline & Et & Pentyl & +1.05 & +0.74 & -0.11 & -0.55 \\
\hline & $\mathrm{Et}$ & $\mathrm{Ph}$ & $+1.05^{\mathrm{b}}$ & +0.75 & -0.06 & -0.54 \\
\hline & $\mathrm{Et}$ & Naphthyl & $+1.13^{\mathrm{b}}$ & +0.73 & -0.12 & -0.60 \\
\hline & $\mathrm{Et}$ & $p-\mathrm{CF}_{3} \mathrm{O}-\mathrm{C}_{6} \mathrm{H}_{4}$ & +1.09 & +0.83 & -0.02 & -0.49 \\
\hline & ${ }^{\mathrm{i}} \mathrm{Pr}$ & $m-C_{3}-C_{6} H_{4}$ & $+1.10^{\mathrm{b}}$ & +0.82 & -0.03 & -0.50 \\
\hline & $\mathrm{Ph}$ & $\mathrm{Ph}$ & $+1.23^{\mathrm{e}}$ & +0.74 & -0.01 & -0.51 \\
\hline & $p-\mathrm{F}-\mathrm{C}_{6} \mathrm{H}_{4}$ & $p-\mathrm{F}-\mathrm{C}_{6} \mathrm{H}_{4}$ & $+0.90^{\mathrm{b}}$ & +0.79 & +0.09 & -0.47 \\
\hline & $p-\mathrm{F}-\mathrm{C}_{6} \mathrm{H}_{4}$ & $m, m, p-\left(\mathrm{CH}_{3} \mathrm{O}\right)_{3}-\mathrm{C}_{6} \mathrm{H}_{4}$ & $+1.05^{\mathrm{b}}$ & +0.76 & -0.01 & -0.51 \\
\hline & $p-\mathrm{F}-\mathrm{C}_{6} \mathrm{H}_{4}$ & Naphthyl & $+1.15^{\mathrm{b}}$ & +0.79 & -0.00 & -0.51 \\
\hline
\end{tabular}

${ }^{\mathrm{a}}$ two electron process; ${ }^{\mathrm{b}}$ irreversible process; ${ }^{\mathrm{c}}$ low temperature, ${ }^{\mathrm{d}} \mathrm{DPV},{ }^{\mathrm{e}}$ overlapped by a further oxidation. 
Concerning the oxidation path, let us consider the comproportionation equilibrium, considering the metal formally bivalent:

$$
[\mathrm{L}(0)-\mathrm{M}(\mathrm{II})-\mathrm{L}(0)]^{2+}+[\mathrm{L}(-\mathrm{I})-\mathrm{M}(\mathrm{II})-\mathrm{L}(-\mathrm{I})]^{0} \rightleftharpoons 2[\mathrm{~L}(-\mathrm{I})-\mathrm{M}(\mathrm{II})-\mathrm{L}(0)]^{+}
$$

the equilibrium constant of which is given by [20,21]:

$$
K_{c o m}=e^{\frac{\Delta E^{\circ !} \cdot F}{R T}}
$$

where $\Delta \mathrm{E}^{\circ}$ is the difference between the formal electrode potentials of the two sequential one-electron oxidations.

Since the comproportionation constant can give a rough evaluation of the charge delocalisation present in the mixed valence monocation $[\mathrm{L}(-\mathrm{I})-\mathrm{M}(\mathrm{II})-\mathrm{L}(0)]^{+}[21]$, the $\mathrm{K}_{\text {com }}$ value of $3 \cdot 10^{4}$ for the sequence $\left[\mathrm{Pd}\left(\mathrm{Et}_{2} \mathrm{timdt}\right)_{2}\right]^{0} /\left[\mathrm{Pd}\left(\mathrm{Et}_{2} \mathrm{timdt}\right)_{2}\right]^{+} /\left[\mathrm{Pd}\left(\mathrm{Et}_{2} \mathrm{timdt}\right)_{2}\right]^{2+}$ suggests that the monocation $\left[\mathrm{Pd}\left(\mathrm{Et}_{2} \mathrm{timdt}\right)_{2}\right]^{+}$should belong to the partially delocalised Robin-Day Class II. A similar conclusion holds for $\left[\mathrm{Pt}\left(\mathrm{Et}_{2} \mathrm{timdt}\right)_{2}\right]^{+}\left(\mathrm{K}_{\mathrm{com}}=8 \cdot 10^{4}\right)$.

As far as the sequential reductions are concerned, it looks likely that all the monoanions $\left[\mathrm{M}\left(\mathrm{Et}_{2} \mathrm{timdt}\right)_{2}\right]^{-}$belong to the completely delocalised Robin Day Class III $\left(\mathrm{M}=\mathrm{Ni}, \mathrm{K}_{\mathrm{com}}=4 \cdot 10^{7} ; \mathrm{M}=\mathrm{Pd}, \mathrm{K}_{\mathrm{com}}=2 \cdot 10^{6} ; \mathrm{M}=\mathrm{Pt}, \mathrm{K}_{\mathrm{com}}=6 \cdot 10^{7}\right)$.

In order to evaluate the inductive effects played by the different substituents in $\left[\mathrm{M}(\mathrm{R}, \mathrm{R} \text { '-timdt })_{2}\right]$, Fig. 2 plots the formal electrode potential for the first reduction process towards the field/inductive parameters $\mathrm{F}$ [22].

As deducible from Table 2, a satisfactory linear correlation holds also for the second reduction process.

The linear correlation found for the $\mathrm{Ni}, \mathrm{Pd}$ and $\mathrm{Pt}$ dithiolenes is described through:

(i) the coefficients $\mathrm{A}$ and $\mathrm{B}$ of the linear equation: $\mathrm{Y}=\mathrm{A} \mathrm{X}+\mathrm{B}$, calculated by the least squares method;

(ii) a statistical estimate of the Error implicit in these coefficients;

(iii) the correlation coefficient R;

(iv) the standard deviation of the fit SD;

(v) the number $\mathrm{N}$ of points considered for the correlation;

(vi) the probability $\mathrm{P}$ that the $\mathrm{R}$ value found could be casual. 
(a)

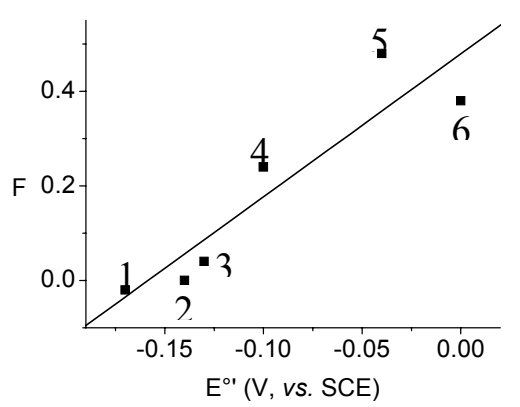

(b)

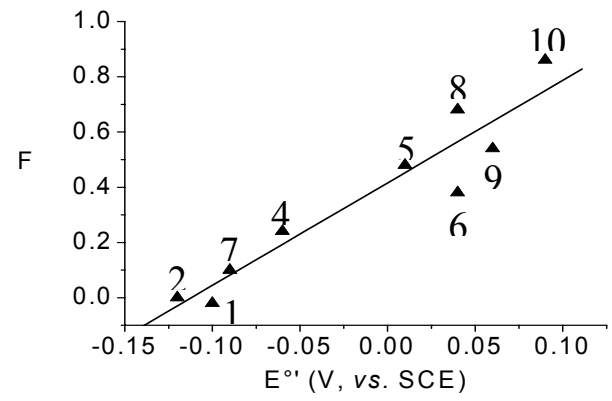

(c)

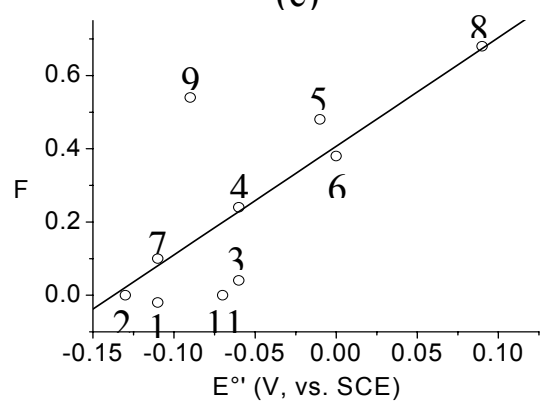

Figure 2. Linear correlation between the formal electrode potentials $\left(\mathrm{E}^{\circ}\right)$ for the first reduction of $\mathrm{Ni}(\quad), \mathrm{Pd}(\boldsymbol{\Delta}), \mathrm{Pt}(\mathrm{O})$ dithiolenes and the field/inductive parameters $\mathrm{F}$. $\mathrm{R}$, R': $1=$ Et, Pentyl; $2=$ Et, Et; $3=\mathrm{Me}, \mathrm{Me} ; 4=\mathrm{Et}, \mathrm{Ph} ; 5=\mathrm{Ph}, \mathrm{Ph} ; 6=\mathrm{Me}, p-\mathrm{Cl}_{-} \mathrm{C}_{6} \mathrm{H}_{4} ; 7$ $=\mathrm{Me},{ }^{\mathrm{i}} \mathrm{Pr} ; 8=p-\mathrm{F}-\mathrm{C}_{6} \mathrm{H}_{4}, p-\mathrm{Cl}-\mathrm{C}_{6} \mathrm{H}_{4} ; 9=\mathrm{Me}, p-\mathrm{NO}_{2}-\mathrm{C}_{6} \mathrm{H}_{4} ; 10=p-\mathrm{F}-\mathrm{C}_{6} \mathrm{H}_{4}, p-\mathrm{NO}_{2}-\mathrm{C}_{6} \mathrm{H}_{4}$; $11=$ Me, Pentyl.

Table 2. Linear Regression Data for the redox processes of [M(R,R'-timdt $\left.)_{2}\right]$ complexes versus the field/inductive parameters $\mathrm{F}$.

\begin{tabular}{|c|c|c|c|c|c|c|c|c|}
\hline \multicolumn{2}{|c|}{$\begin{array}{c}\text { Redox } \\
\text { process }\end{array}$} & \multicolumn{2}{|c|}{ Parameter } & \multirow{3}{*}{$\begin{array}{c}\text { Error } \\
0.07 \\
0.64\end{array}$} & \multirow{3}{*}{$\begin{array}{c}\mathbf{R} \\
0.92\end{array}$} & \multirow{3}{*}{$\begin{array}{c}\text { SD } \\
0.09\end{array}$} & \multirow{3}{*}{$\frac{\mathbf{N}}{6}$} & \multirow{3}{*}{$\begin{array}{c}\mathbf{P} \\
0.01\end{array}$} \\
\hline \multirow{6}{*}{ 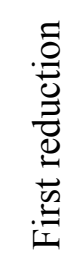 } & $\mathrm{Ni}$ & A & 0.48 & & & & & \\
\hline & & B & 3.02 & & & & & \\
\hline & $\mathrm{Pd}$ & A & 0.42 & 0.04 & 0.95 & 0.10 & 9 & 0.00 \\
\hline & & B & 3.71 & 0.47 & & & & \\
\hline & $\mathrm{Pt}$ & A & 0.41 & 0.07 & 0.76 & 0.18 & 10 & 0.01 \\
\hline & & B & 2.97 & 0.91 & & & & \\
\hline \multirow{6}{*}{ 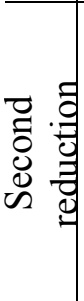 } & $\mathrm{Ni}$ & A & 1.88 & 0.52 & 085 & 12 & 6 & 003 \\
\hline & & B & 3.05 & 0.92 & 0.05 & 0.12 & 0 & 0.05 \\
\hline & Dd & A & 1.92 & 0.29 & 0 & 014 & 0 & 000 \\
\hline & 10 & B & 3.87 & 0.72 & 0.70 & 0.14 & (7) & 0.00 \\
\hline & Dt & A & 1.60 & 0.77 & 053 & ( & 10 & 17 \\
\hline & Ft & B & 2.61 & 1.49 & 0.55 & 0.25 & 10 & 0.12 \\
\hline
\end{tabular}


Since the $\mathrm{F}$ values of a few substituents are not available in literature, we tentatively extrapolated them from the linear correlation fit, Table 3.

Table 3. Field/inductive parameters $\mathrm{F}$ for few substituents extrapolated from the linear regression fit.

\begin{tabular}{c|cccc}
\hline \multirow{2}{*}{$\begin{array}{c}\text { Substituent } \\
p \text {-Ome- } \mathrm{C}_{6} \mathrm{H}_{4}\end{array}$} & $\mathbf{N i}$ & $\mathbf{P d}$ & $\mathbf{P t}$ & Average \\
\hline$m-\mathrm{CF}_{3}-\mathrm{C}_{6} \mathrm{H}_{4}$ & 0.08 & - & - & 0.08 \\
& 0.11 & 0.15 & 0.12 & 0.13 \\
$m, m, p-\left(\mathrm{CH}_{3} \mathrm{O}\right)_{3}-\mathrm{C}_{6} \mathrm{H}_{4}$ & - & 0.13 & 0.02 & 0.08 \\
$m-\mathrm{CF}_{3}-\mathrm{C}_{6} \mathrm{H}_{4} \mathrm{CH}_{2}$ & - & 0.16 & 0.16 & 0.16 \\
Naphthyl & 0.10 & 0.08 & 0.02 & 0.05 \\
\hline
\end{tabular}

Unexpectedly, no good linear correlations have been obtained for the oxidation processes. At a first instance, we assume that not easily determined effects might add to the inductive effects in controlling the $\mathrm{E}^{\mathrm{O}}$, values, thus contributing to the departure from the linear trend.

As a further support, we recently evidenced that inductive effects also play an important role in the HOMO-LUMO NIR transition [10].

\section{EPR analysis}

It is well-known that neutral dithiolenes are not radical in nature and accordingly all the neutral complexes $\left[\mathrm{M}\left(\mathrm{R}, \mathrm{R}^{\prime} \text {-timdt }\right)_{2}\right]$ resulted EPR silent. As a typical example, Fig. 3 shows the X-band EPR spectra of the monoanion $\left[\mathrm{Ni}\left(\mathrm{Et}_{2}-\right.\right.$ timdt) $\left.{ }_{2}\right]^{-}$obtained by controlled potential coulometry in $\mathrm{CH}_{2} \mathrm{Cl}_{2}$ solution at -20 ${ }^{\circ} \mathrm{C}$.

Under glassy conditions, the lineshape is largely anisotropic with a well resolved rhombic symmetry typical of $S=1 / 2$ system. As reported in Table 4 , the $g_{i}$ values significantly differ from the $g_{\text {electron }}$ value $(2.0023)$ indicating that the SOMO possesses a mixed metal-ligand nature. 
Concomitantly, the relatively small $\delta g=g_{1}-g_{h}=0.062(5)$ testifies for the main delocalisation of the unpaired electron over the ligand frame. This is in agreement with the occupancy of the $b_{2 g}$ LUMO of the neutral species by the unpaired electron of the monoanionic form. In fact, DFT- calculations showed that this is a $\pi^{*}-\mathrm{MO}$ with a remarkable contribution of the $\mathrm{d}_{\mathrm{xy}}$ a.o. of the central metal [7,9-12]. There is no evidence for magnetic interactions between the unpaired electron and the ligand nuclei $\left({ }^{14} \mathrm{~N}: \mathrm{I}=1\right.$, natural abundance $=99.6 \%$; $\left.{ }^{1} \mathrm{H}\right)$, probably because the actual $\Delta \mathrm{H}_{\text {anisotropic }}$ linewidth overlaps the underlying low magnetic couplings (if any). Upon raising the temperature to fluid solution $(\mathrm{T}=178 \mathrm{~K})$, the rhombic spectrum collapses in a narrow isotropic spectrum.
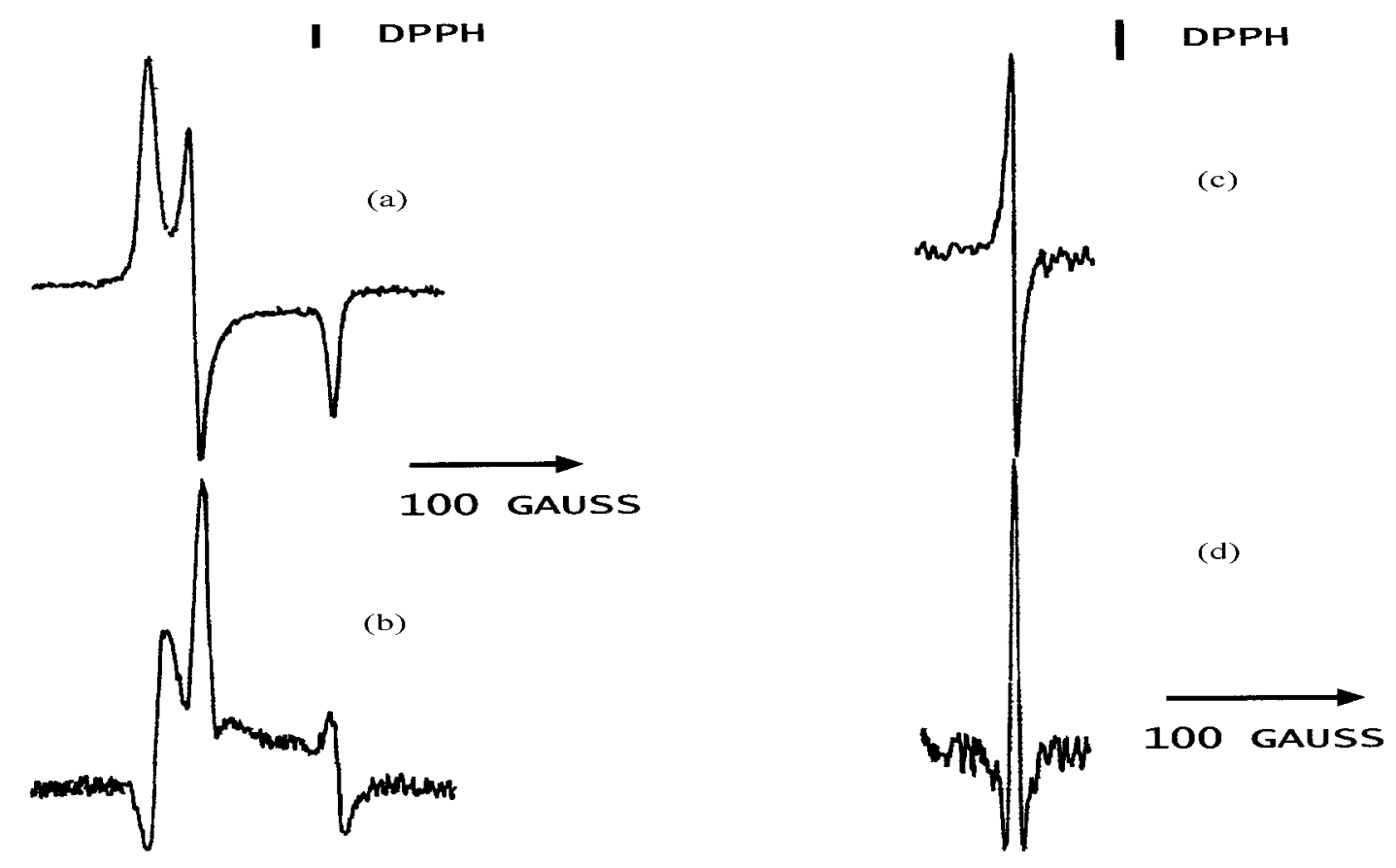

Figure 3. $\mathrm{X}$-band EPR spectra of the monoanion $\left[\mathrm{Ni}\left(\mathrm{Et}_{2} \mathrm{timdt}\right)_{2}\right]^{-}$in $\mathrm{CH}_{2} \mathrm{Cl}_{2}$ solution containing $\left[\mathrm{NBu}_{4}\right]\left[\mathrm{PF}_{6}\right]\left(0.2 \mathrm{~mol} \mathrm{dm}^{-3}\right)$. (a) First derivative at $110 \mathrm{~K}(\mathrm{LN})$; (b) second derivative at $110 \mathrm{~K}(\mathrm{LN})$; (c) first derivative at $285 \mathrm{~K}$; (d) second derivative at $285 \mathrm{~K}$.

A single unresolved signal is present characterized by a linewidth $\Delta \mathrm{H}_{\text {isotropic }}$ that strongly depends on the temperature $\left[\Delta \mathrm{H}_{\text {isotropic }} \geq \mathrm{a}_{\text {isotropic }}\left({ }^{14} \mathrm{~N},{ }^{1} \mathrm{H}\right)\right]$. The absence 
of nuclear magnetic interactions is confidently assigned to the nature abundance of the active nuclei ${ }^{61} \mathrm{Ni}\left({ }^{61} \mathrm{Ni}: \mathrm{I}=3 / 2\right.$, natural abundance $\left.=1.19 \%\right)$. In the range from $178 \mathrm{~K}$ to $285 \mathrm{~K}$ the primary geometry of monoanion is retained in that the $<\mathrm{g}>$ and the $\mathrm{g}_{\text {isotropic }}$ values are quite identical [14]. Upon refreezing the solution to $100 \mathrm{~K}$, the original spectrum is restored, thus proving the stability of the monoanion.

The LN spectrum of $\left[\mathrm{Pd}\left(\mathrm{Et}_{2}-\mathrm{timdt}\right)_{2}\right]^{-}$also shows a rhombic lineshape $(\mathrm{S}=1 / 2)$. In the $g_{l}$ field zone four signals of low intensity (satellite peaks) are present, as a part of the six absorptions theoretically expected from the presence of the isotopic species ${ }^{105} \mathrm{Pd}\left({ }^{105} \mathrm{Pd}: \mathrm{I}=5 / 2\right.$, natural abundance $\left.=22.23 \%\right)$. These minor peaks put in evidence the contribution of the $4 \mathrm{~d}$ metal orbitals to the SOMO, even if, based on the pertinent $g_{i}$ values and the related $\Delta g=0.065$ (5) parameter, it results mainly ligand centred. No evidence for palladium, nitrogen or hydrogen interactions is found in the $g_{i}$ spectral zones as a consequence of broad anisotropic linewidths $\left[\Delta \mathrm{H}_{\mathrm{i}} \geq \mathrm{a}_{\text {anisotropic }}\left({ }^{105} \mathrm{Pd},{ }^{14} \mathrm{~N},{ }^{1} \mathrm{H}\right)\right]$. Also in this case, raising the temperature at the glassy-fluid transition makes the anisotropic features to drop out and one single unresolved signal appears, the linewidth $\Delta \mathrm{H}_{\text {isotropic }}$ of which displays the typical temperature dependence $\left[\Delta \mathrm{H}_{\text {isotropic }} \geq \mathrm{a}_{\text {isotropic }}\left({ }^{105} \mathrm{Pd}\right.\right.$, $\left.\left.{ }^{14} \mathrm{~N},{ }^{1} \mathrm{H}\right)\right] .\left[\Delta \mathrm{H}_{\text {isotropic }} \geq \mathrm{a}_{\text {isotropic }}\left({ }^{105} \mathrm{Pd},{ }^{14} \mathrm{~N},{ }^{1} \mathrm{H}\right)\right]$. In the range from $178 \mathrm{~K}$ to $220 \mathrm{~K}$ the primary geometry of monoanion is retained in that the $<\mathrm{g}>$ and the $\mathrm{g}_{\text {isotropic }}$ values are quite identical. Also in this case, rapidly refreezing the fluid solution restores the original anisotropic spectrum.

Finally, $\left[\mathrm{Pt}\left(\mathrm{Et}_{2} \text {-timdt }\right)_{2}\right]^{-}$exhibits EPR features substantially similar to those above described for $\left[\mathrm{Ni}\left(\mathrm{Et}_{2}-\mathrm{timdt}\right)_{2}\right]^{-}$and $\left[\mathrm{Pd}\left(\mathrm{Et}_{2}-\mathrm{timdt}\right)_{2}\right]^{-}$, but for the presence in the LN spectrum of the typical doublet deriving from the interaction of the unpaired electron with the magnetically active Platinum nucleus $\left({ }^{195} \mathrm{Pt}\right.$ : $\mathrm{I}=1 / 2$, natural abundance $=33.8 \%)$ as satellite peaks $\left[\Delta \mathrm{H}_{\text {anisotropic }} \geq \mathrm{a}_{\text {isotropic }}\left({ }^{14} \mathrm{~N},{ }^{1} \mathrm{H}\right)\right]$. Once again, at the glassy-fluid transition the rhombic spectrum collapses in an unresolved isotropic signal $\left[\Delta \mathrm{H}_{\text {isotropic }} \geq \mathrm{a}_{\text {isotropic }}\left({ }^{195} \mathrm{Pt},{ }^{14} \mathrm{~N},{ }^{1} \mathrm{H}\right)\right]$. 
Table 4. X-band EPR parameters for $\left[\mathrm{M}\left(\mathrm{Et}_{2} \mathrm{timdt}\right)_{2}\right]^{-}(\mathrm{M}=\mathrm{Ni}, \mathrm{Pd}, \mathrm{Pt})$ and $\left[\mathrm{Pt}_{2}\left(\mathrm{Et}_{2} \mathrm{timdt}\right)_{2}\right]^{+}$in $\mathrm{CH}_{2} \mathrm{Cl}_{2}$ solution.

\begin{tabular}{|c|c|c|c|c|c|c|c|c|c|c|c|c|}
\hline $\mathbf{M}$ & $\mathbf{g}_{\mathbf{I}}$ & $\mathbf{g}_{\mathbf{m}}$ & $\mathbf{g}_{\mathbf{h}}$ & $<\mathbf{g}>$ & $\mathbf{g}_{\text {iso }}$ & $\Delta \mathbf{g}$ & $\mathbf{a}_{1}$ & $\mathbf{a}_{\mathbf{m}}$ & $\mathbf{a}_{\mathbf{h}}$ & $<\mathbf{a}>$ & $\mathbf{a}_{\text {iso }}$ & $\Delta \mathbf{H}_{\text {iso }}$ \\
\hline $\mathrm{Ni}$ & $2.058(5)$ & $2.042(5)$ & $1.996(5)$ & $2.032(5)$ & $2.025(5)^{\mathrm{a}}$ & $0.062(5)$ & $\leq \Delta \mathrm{H}_{\text {aniso }}$ & $\leq \Delta \mathrm{H}_{\text {aniso }}$ & $\leq \Delta \mathrm{H}_{\text {aniso }}$ & $\leq \Delta \mathrm{H}_{\text {aniso }}$ & $\leq \Delta \mathrm{H}_{\text {iso }}$ & $\begin{array}{c}20(5)(\mathrm{T}=200 \mathrm{~K}) \\
10(5)(\mathrm{T}=260 \mathrm{~K}) \\
7(5)(\mathrm{T}=285 \mathrm{~K})\end{array}$ \\
\hline $\mathrm{Pd}$ & $2.038(5)$ & $2.024(5)$ & $1.973(5)$ & $2.012(5)$ & $2.012(5)^{\mathrm{b}}$ & $0.065(5)$ & $10(5)$ & $\leq \Delta \mathrm{H}_{\text {aniso }}$ & $\leq \Delta \mathrm{H}_{\text {aniso }}$ & $\leq \Delta \mathrm{H}_{\text {aniso }}$ & $\leq \Delta \mathrm{H}_{\text {iso }}$ & $\begin{array}{l}30(5)(\mathrm{T}=180 \mathrm{~K}) \\
17(5)(\mathrm{T}=200 \mathrm{~K}) \\
12(5)(\mathrm{T}=220 \mathrm{~K})\end{array}$ \\
\hline Pt monoanion & $2.101(5)$ & $2.070(5)$ & $1.881(5)$ & $2.017(5)$ & $2.020(5)^{\mathrm{c}}$ & $0.220(5)$ & $40(5)$ & $80(5)$ & $75(5)$ & $65(5)$ & $\leq \Delta \mathrm{H}_{\text {iso }}$ & $\begin{array}{l}75(8)(\mathrm{T}=205 \mathrm{~K}) \\
80(8)(\mathrm{T}=275 \mathrm{~K})\end{array}$ \\
\hline Pt monocation & $2.039(8)$ & $2.017(8)$ & $1.979(8)$ & $2.012(8)$ & --- & $0.069(8)$ & $\leq \Delta \mathrm{H}_{\text {aniso }}$ & $\leq \Delta \mathrm{H}_{\text {aniso }}$ & $\leq \Delta \mathrm{H}_{\text {aniso }}$ & $\leq \Delta \mathrm{H}_{\text {aniso }}$ & --- & --- \\
\hline
\end{tabular}

$\mathbf{a}_{\mathbf{i}}, \Delta \mathbf{H}_{\text {iso }}$ values are express in Gauss; $<\mathrm{g}>=\left(\mathrm{g}_{1}+\mathrm{g}_{\mathrm{m}}+\mathrm{g}_{\mathrm{h}}\right) / 3 ;<\mathrm{a}>=\left(\mathrm{a}_{1}+\mathrm{a}_{\mathrm{m}}+\mathrm{a}_{\mathrm{h}}\right) / 3 ; \mathbf{l}=$ low field, $\mathbf{m}=$ medium field, $\mathbf{h}=$ high field; ${ }^{\mathrm{a}}: \mathrm{T}=285 \mathrm{~K}$, ${ }^{\mathrm{b}}: \mathrm{T}=220 \mathrm{~K},{ }^{\mathrm{c}}: \mathrm{T}=275 \mathrm{~K}$. 
In the range from $178 \mathrm{~K}$ to $275 \mathrm{~K}$ the primary geometry of monoanion is retained in that the $<\mathrm{g}>$ and the $\mathrm{g}_{\text {isotropic }}$ values are quite identical. The rapid refreezing of the fluid solution quantitatively restores the original signal.

The $\mathrm{LN}$ spectrum of the monocation $\left[\mathrm{Pt}\left(\mathrm{Et}_{2} \mathrm{timdt}\right)_{2}\right]^{+}$is not well resolved as that of $\left[\mathrm{Pt}\left(\mathrm{Et}_{2} \mathrm{timdt}\right)_{2}\right]^{-}$. It shows anisotropic features typical of $\mathrm{S}=1 / 2$ paramagnetic systems displaying a broad rhombic pattern. No spectral resolution of the three rhombic regions is evident due to important linebroadening effects $\left[\Delta \mathrm{H}_{\mathrm{i}} \geq \mathrm{a}_{\mathrm{i}}\right.$ $\left.\left({ }^{195} \mathrm{Pt},{ }^{14} \mathrm{~N},{ }^{1} \mathrm{H}\right) ; \Delta \mathrm{H}_{1}=30(5) \mathrm{G}, \Delta \mathrm{H}_{\mathrm{m}}=40(5) \mathrm{G}, \Delta \mathrm{H}_{\mathrm{h}}=35(5) \mathrm{G}\right]$. As for the monoanion, the $\langle g\rangle>g_{\text {electron }}$ suggests metallic contribution to the anisotropic lineshape even if to a minor extent with respect to the monoanion $\left(\Delta \mathrm{g}\left(\left[\mathrm{PtL}_{2}\right]^{-}\right)>\right.$ $\Delta \mathrm{g}\left(\left[\mathrm{PtL}_{2}\right]^{+}\right)$. Raising the temperature to fluid solution leads to EPR inactivity, and refreezing the solution to glassy conditions in part restores the original signal, thus indicating a relative chemical instability of the monocation.

The temperature dependent EPR parameters for the above discussed paramagnetic species are summarized in Table 4.

It is noted that the actual $\Delta \mathrm{g}$ parameters point out that the Pt monoanion affords the highest S.O. coupling contribution to the actual SOMO [23], indicating that the pertinent unpaired electron possess a metal-centred character, which is also higher than that of the corresponding Pt monocation.

\section{Conclusions}

The intense NIR absorption exhibited by metal-dithiolenes is calling interest on its possible application to laser technologies and photoconduction. In this connection, the study on the electrochemical properties and of the EPR spectroscopy plays a fundamental role in understanding the nature of the frontier orbitals involved in the $\pi-\pi^{*}$ transition. Thus, the electrochemical properties of a wide series of substituted $\left[\mathrm{M}\left(\mathrm{R}, \mathrm{R}^{\prime} \text { 'timdt }\right)_{2}\right]$ complexes have been studied in order to determine the influence played by both the metal and the substituents on their physical-chemical properties. The redox aptitude of the series $\left[\mathrm{M}\left(\mathrm{R}, \mathrm{R}^{\prime} \text { timdt }\right)_{2}\right]$ evidences that both the metal and the ligand influence the number and the location of the electron transfer processes. All the complexes can reversibly 
access the corresponding mono- and di-anions through separate reductions, which are mainly located on the ligand. This path foreshadows an electronic communication between the reduction sites. In particular, the monoanions can be assigned to the completely delocalised Robin Day mixed-valence Class III. A different behaviour is found for the anodic path, in that all the nickel complexes display a single, partially reversible, two-electron step, whereas the palladium and platinum complexes undergo two separate one-electron removals, which are reversible in the short times of cyclic voltammetry. In agreement to what previous reported, the influence of the groups $\mathrm{R}$ and $\mathrm{R}$ ' results to be mainly of inductive type, particularly as far as the reduction processes are concerned. As a matter of fact, the oxidation processes likely involve more complicate effects in that no linear dependence was found between formal electrode potentials and the inductive parameters. The EPR spectra are very useful in confirming the previously reported DFT-calculations, according to which the metal contribution to the LUMO increases on passing from $\mathrm{Ni}$ to $\mathrm{Pd}$ and $\mathrm{Pt}$ [9]. In agreement, the EPR analysis of $\left[\mathrm{M}\left(\mathrm{Et}_{2} \mathrm{timdt}\right)_{2}\right]^{-}$monoanions indicates that, independently from the nature of the central metal, the LUMO is basically ligand-centred with a metal contribution which is EPR detectable (in particular for $\mathrm{Pd}, \mathrm{Pt}$ ) [24]. Moreover, the EPR spectra of all the monoanions under LN conditions exhibit a rhombic pattern, suggesting the same primary geometry with some minor differences (due to the expected differences in angles and bond lengths). As a matter of fact, in glassy solution, the metallic contribution in complex $\left[\mathrm{Pt}\left(\mathrm{Et}_{2} \mathrm{timdt}\right)_{2}\right]^{-}$appears to be the highest one, whereas the platinum monocation exhibits reduced metallic character, indicating that the unpaired spin density is spread over the ligand frame.

\section{Acknowledgements}

P.Z. gratefully acknowledges the financial support from the University of Siena (PAR 2003). 


\section{References}

1. (a) Molecular Nonlinear Optics: Materials, Physical and Devices (Ed.: J. Zyss), Academic Press, Boston, MA, 1993; (b) C.-T. Chen, S.-Y. Liao, K.J. Lin, L.-L. Lai, Adv. Mater. 10 (1998) 334; (c) D.-L. Long, W.-T- Wong, S. Shi, X.-Q. Xin, J.-S Huang, J.Chem. Soc., Dalton Trans. (1997) 4361; (d) Z. Sun, M. Tong, H. Zeng, L. Ding, Z. Wang, Z. Xu, J. Dai, G. Bian, Chem.Phys. Lett. 342 (2001) 323.

2. J.R. Ferraro, J.M. Williams, Introduction to Synthetic Electrical Conductors, Academic, New York, 1987.

3. U.T. Mueller-Westerhoff, B. Vance, D.I. Yoon, Tetrahedron 47 (1991) 909.

4. F. Bigoli, P. Deplano, F.A. Devillanova, V. Lippolis, P.J. Lukes, M.L. Mercuri, M.A. Pellinghelli, E.F. Trogu, J. Chem. Soc., Chem. Commun. (1995) 371.

5. P. Zanello, E. Grigiotti, in Homoleptic, Mononuclear Transition Metal Complexes of 1,2- Dithiolenes: Updating their Electrochemical-toStructural Properties (A.J.L. Pombeiro, C. Amatore, Eds. Fontis Media and Marcel Dekker, in press).

6. F. Bigoli, P. Deplano, F.A. Devillanova, J.R. Ferraro, V. Lippolis, P.J. Lukes, M.L. Mercuri, M.A. Pellinghelli, E.F. Trogu, Inorg. Chem. 36 (1997) 1218.

7. M. Arca, F. Demartin, F.A. Devillanova, A. Garau, F. Isaia, F. Lelj, V. Lippolis, S. Pedraglio, G. Verani, J. Chem. Soc., Dalton Trans. (1998) 3731.

8. F. Bigoli, P. Deplano, M.L. Mercuri, M.A. Pellinghelli, G. Pintus, E.F. Trogu, G. Zonnedda, H.H. Wang, J.M. Williams, Inorg. Chim. Acta 273 (1998) 175.

9. M.C. Aragoni, M. Arca, F. Demartin, F.A. Devillanova, A. Garau, F. Isaia, F. Lelj, V. Lippolis, G. Verani, J. Am. Chem. Soc. 121 (1999) 7098.

10. M.C. Aragoni, M. Arca, T. Cassano, C. Denotti, F.A. Devillanova, R. Frau, F. Isaia, F. Lelj, V. Lippolis, L. Nitti, P. Romaniello, R. Tommasi, G. Verani, Eur. J. Inorg. Chem. (2003) 1939. 
11. T. Cassano, R. Tommasi, L. Nitti, M.C. Aragoni, M. Arca, C. Denotti, F.A. Devillanova, F. Isaia, V. Lippolis, F. Lelj, P. Romaniello, J. Chem. Phys. 118 (2003) 5995.

12. P. Romaniello, M.C. Aragoni, M. Arca, T. Cassano, C. Denotti, F.A. Devillanova, F. Isaia, V. Lippolis, F. Lelj, R. Tommasi, J. Phys. Chem. (2003) in press.

13. M.C. Aragoni, M. Arca, T. Cassano, C. Denotti, F.A. Devillanova, F. Isaia, V. Lippolis, D. Natali, L. Nitti, M. Sampietro, R. Tommasi, Inorg. Chem. Comm. 5 (2002) 869.

14. D. Natali, M. Sampietro, M. Arca, C. Denotti, F.A. Devillanova, Synth. Met. 137 (2003) 1489.

15. J.A. McCleverty, M.D. Ward, Proc. Indian Acad. Sci. 114 (2002) 291.

16. J.A. McCleverty, M.D. Ward, J. Chem. Soc., Dalton Trans. (2001) 275.

17. M.C. Aragoni, M. Arca, C. Denotti, F.A. Devillanova, E. Grigiotti, F. Isaia, F. Lashi, V. Lippolis, L. Pala, A.M.Z. Slawin, P. Zanello, J.D. Woollins, Eur. J. Inorg. Chem. (2003) 1291.

18. M.C. Aragoni, M. Arca, F.A. Devillanova, F. Isaia, V. Lippolis, A. Mancini, L. Pala, A.M.Z. Slawin, J.D. Woollins, J. Chem. Soc., Chem. Comm. (2003) 2226.

19. F. Bigoli, S. Curreli, P. Deplano, L. Leoni, M.L. Mercuri, M.A. Pellinghelli, A. Serpe, E.F. Trogu, J. Chem. Soc., Dalton Trans. (2002) 1985.

20. A.W. Bott, Curr. Sep. 16 (1997) 61.

21. (a) V. Palaniappan, R.M. Singru, U.C. Agarwala, Inorg Chem. 27 (1988) 181; (b) D. Astruc, Electron Transfer and Radical Processes in TransitionMetal Chemistry, Wiley-VCH, New York, 1995; (c) B.S. Brunschwig, N. Sutin, Coord. Chem. Rev. 187 (1999) 233.

22. C. Hansch, A. Leo, R. Taft, Chem. Rev. 91 (1991) 165.

23. F.E. Mabbs, D. Collison, Electron Paramagnetic Resonance of d Transition Metal Compounds, in Studies in Inorganic Chemistry, vol. 16, Elsevier, New York, 1992.

24. J.A. McCleverty, Prog. Inorg. Chem. 10 (1968) 49. 